\title{
Feasibility of concentrating potassium minerals from Verdete ore by cell
} flotation

\section{Viabilidade de concentrar minerais de potássio do minério Verdete por flotação em célula}

Article Info:

Article history: Received 2021-04-12 / Accepted 2021-05-17/ Available online 2021-05-17

doi: 10.18540/jcecvl7iss2pp12338-01-12e

Laryssa Batista Christina Cordeiro

ORCID: https://orcid.org/0000-0002-3233-5812

Federal University of Uberlândia, Brazil

E-mail: laryssabcordeiro@gmail.com

Michelly dos Santos Oliveira

ORCID: https://orcid.org/0000-0003-0660-4553

Federal Centre for Technological Education of Minas Gerais, Brazil

E-mail: michelly@cefetmg.br

Kátia Dionísio de Oliveira

ORCID: https://orcid.org/0000-0002-6267-5383

Independent Researcher, Brazil

E-mail: katiadionisioliveira@gmail.com

Marcos Antônio de Souza Barrozo

ORCID: https://orcid.org/0000-0002-8873-162X

Federal University of Uberlândia, Brazil

E-mail: masbarrozo@ufu.br

Cícero Naves de Ávila Neto

ORCID: https://orcid.org/0000-0002-5835-6670

Federal University of Uberlândia, Brazil

E-mail: avilaneto@ufpr.br

\section{Resumo}

Um minério silicatado com teor de $\mathrm{K}_{2} \mathrm{O}$ acima de $10 \%$, encontrado na região central de Minas Gerais (Brasil), conhecido como Verdete, foi flotado em célula de flotação. O objetivo foi avaliar o comportamento de flotação dos constituintes do minério (glauconita, muscovita, feldspato potássico e quartzo) em relação ao uso de diferentes coletores (sabão de ácidos graxos obtidos a partir de óleo de arroz, amina e ácido oleico) e depressores (amido de milho gelatinizado e silicato de sódio). Também foi avaliada a flotação dos produtos de calcinação do Verdete com $\mathrm{MgCl}_{2}$ e $\mathrm{CaCl}_{2}$. A recuperação em massa da flotação realizada com Verdete atingiu um máximo de $53 \%$ nos casos em que amina e silicato de sódio foram usados como coletor e depressor, respectivamente. A recuperação em massa demonstrou ser diretamente proporcional à dosagem do coletor e também foi influenciada pelo tipo de depressor. A calcinação do Verdete com $\mathrm{MgCl}_{2} \cdot x \mathrm{H}_{2} \mathrm{O}$ consumiu parcialmente as micas e gerou $\mathrm{MgO}$. A flotação deste produto de calcinação concentrou $\mathrm{MgO}$ na fração flotada, atingindo $93 \%$ quando o ácido oleico foi usado como coletor.

Palavras-chave: Célula de flotação. Verdete. Micas. Feldspato potássico. 


\begin{abstract}
A silicate ore with $\mathrm{K}_{2} \mathrm{O}$ content above $10 \%$, found in the central region of Minas Gerais (Brazil), called Verdete, was floated in flotation cell. The goal was to evaluate the flotation behaviour of the ore constituents (glauconite, muscovite, K-feldspar and quartz) relative to the use of different collectors (fatty acid soap obtained from rice oil, amine and oleic acid) and depressors (gelatinized cornstarch and sodium silicate). Flotation of the calcination products of Verdete with $\mathrm{MgCl}_{2}$ and $\mathrm{CaCl}_{2}$ were also evaluated. Mass recovery of flotation carried out with Verdete reached a maximum of 53\% when amine and sodium silicate were used as collector and depressant, respectively. Mass recovery was directly proportional to collector dosage, and was also influenced by the type of depressor. Calcination of Verdete with $\mathrm{MgCl}_{2} \cdot x \mathrm{H}_{2} \mathrm{O}$ partially consumed the micas and generated $\mathrm{MgO}$. Flotation of this calcination product concentrated $\mathrm{MgO}$ in the floated fraction, reaching $93 \%$ when oleic acid was used as collector.
\end{abstract}

Keywords: Flotation cell. Verdete. Micas. K-feldspar.

\title{
1. Introduction
}

The central region of the state of Minas Gerais (Brazil) has a deposit of silicate ore, known as Verdete, composed mostly of a mixture of micas (glauconite and muscovite), K-feldspar and quartz, with $\mathrm{K}_{2} \mathrm{O}$ content above $10 \%$. The ore is considered a potential feedstock for production of Kbearing fertilizers in Brazil, where the production of $\mathrm{KCl}$ is restricted to the Taquari-Vassouras mine/plant complex in Sergipe state.

To obtain a more concentrated K-bearing product, concentration techniques such as flotation may be used. In the case of Verdete, the idea is to separate the micas and K-feldspar from quartz, which is not a trivial procedure, since these silicates have similar surface properties. Feldspar is conventionally separated from quartz by using hydrofluoric acid as activator for the feldspar and a cationic collector (amine) (Sulaymonova et al., 2018). Hydrofluoric acid creates a large difference in the zeta potentials of the two minerals, since as the zeta potential of feldspar becomes negative, that of quartz approaches zero. It is also known that the amine ion alone does not sufficiently adsorb in feldspar to promote flotation in acidic media (Larsen and Kleiv, 2016).

In addition to being a very corrosive liquid and presenting a potential risk to the environment in case of improper disposal, hydrofluoric acid is a powerful contact poison and relatively expensive (Larsen and Kleiv, 2016; El-Salmawy et al., 1993). Thus, the use of other reagents should be investigated. Specifically, flotation of the Verdete ore has not been studied yet, which opens up a range of possibilities for the process. Calcination of Verdete prior to flotation is one of these possibilities. Chlorine salts have the potential to break down the structure of K-bearing minerals and release the element in the form of silvite $(\mathrm{KCl})$, as well as other by-products. Silvite can then be separated from the mineral mixture, which includes the presence of other salts produced during calcination, through froth flotation. The separation of silvite from halite is an interesting example of how flotation can be used for this purpose (Huang et al., 2019; Monte and Oliveira, 2004).

This work aims to characterize Verdete and its calcination products and obtain information in order to make the cell flotation process viable as an attempt to separate the K-bearing minerals from those that do not contain potassium. The Verdete ore was floated with different collectors (fatty acid soap obtained from rice oil, amine Flotigam EDA and oleic acid) and depressors (gelatinized cornstarch and sodium silicate). In addition, flotation was also performed on the calcination products of Verdete with $\mathrm{MgCl}_{2}$ and $\mathrm{CaCl}_{2}$. The technical information and the experimental data in this work may contribute with technical information and experimental data for the process of concentrating Verdete in flotation cell. 


\section{Materials and Methods}

\subsection{Sample Preparation}

The sample of Verdete was collected randomly from the rock outcrop in the central region of the state of Minas Gerais, Brazil (UTM 23K 7884678/426568), inside the municipalities of Cedro do Abaeté and Quartel Geral. The ore was comminuted twice with the aid of a hammer mill, and then fed to a ball mill $(151 \mathrm{~L})$, operating at $60 \%$ critical speed $(33 \mathrm{rpm})$, for wet milling. The ground ore was wet sieved with a 100-mesh Tyler sieve $(149 \mu \mathrm{m})$, dried for $12 \mathrm{~h}$ at $393 \mathrm{~K}$ and homogenized for use in flotation tests.

$\mathrm{MgCl}_{2} \cdot x \mathrm{H}_{2} \mathrm{O}$ and $\mathrm{CaCl}_{2} \cdot 2 \mathrm{H}_{2} \mathrm{O}$ were dehydrated at $873 \mathrm{~K}$ for $1 \mathrm{~h}\left(20 \mathrm{~K} \mathrm{~min}^{-1}\right)$ in a muffle furnace. Calcination of Verdete $(500 \mathrm{~g})$ with dried $\mathrm{MgCl}_{2}(175 \mathrm{~g})$ or $\mathrm{CaCl}_{2}(408 \mathrm{~g})$ salts was carried out at $1173 \mathrm{~K}$ for $1 \mathrm{~h}\left(20 \mathrm{~K} \mathrm{~min}^{-1}\right)$ in a muffle furnace. Similar calcination methodologies have been employed elsewhere (Santos et al., 2015). The calcined samples were sieved in a 100-mesh Tyler sieve and named $\mathrm{VM}\left(\right.$ Verdete $\left.+\mathrm{MgCl}_{2}\right)$ and $\mathrm{VC}\left(\right.$ Verdete $\left.+\mathrm{CaCl}_{2}\right)$.

\subsection{Flotation Tests}

Flotation tests were performed using Verdete, or the calcined products VM or VC. Fatty acid soap obtained from rice oil (2.5 wt. \%), amine Flotigam EDA (2 wt. \%) and oleic acid (2.5 wt. \%) were used as collectors. Gelatinized cornstarch (3 wt. \%) and sodium silicate $(3 \mathrm{wt} . \%)$ were used as depressants. The pulp was preconditioned by mechanical agitation at $50 \%$ solids and $1100 \mathrm{rpm}$ for 5 min with each reagent. The $\mathrm{pH}$ was adjusted to 10 with a $10 \% \mathrm{NaOH}$ solution.

Batch flotation tests were performed on Denver type flotation cells, with useful volumes of $1.5 \mathrm{~L}$ (for flotation of Verdete) and 1.2 L (for flotation of samples VM and VC). The fraction of solids within the cell was maintained at $33 \%$ for both Verdete and samples VM and VC. As sample preconditioning was performed inside the cell itself, flotation started when airflow was switched on. The floated material was collected until the foaming stopped. Floated and non-floated materials were identified, dried at $373 \mathrm{~K}$ and weighed after drying. Mass recovery (R) was calculated by Equation 1, where MF and MNF are the masses of floated and non-floated materials.

$R(\%)=\frac{M_{F}}{M_{F}+M_{N F}}$

\subsection{Characterization}

X-ray diffraction (XRD) patterns were recorded with a Shimadzu XRD-6000 diffractometer employing $\mathrm{Cu} \mathrm{K \alpha}$ radiation $(\lambda=1.54056 \AA)$ with $\mathrm{Ni}$ filter, $40 \mathrm{kV}$ voltage and $30 \mathrm{~mA}$ current, as also adopted in other works (Schimicoscki et al., 2020; Tomaz and Ávila-Neto, 2021). The $2 \theta$ angle was scanned from $5^{\circ}$ to $45^{\circ}$ with scanning rate of $1.2{ }^{\circ} \mathrm{min}^{-1}$. The diffraction lines were identified by comparison with XRD standards obtained in the Inorganic Crystal Structure Database (ICSD).

Thermogravimetric analysis (TGA) was carried out with a Shimadzu instrument (Model DTG-60H). The experiment was performed using $6 \mathrm{mg}$ of sample, with heating from room temperature to $1443 \mathrm{~K}$ with a rate of $10 \mathrm{~K} \mathrm{~min}^{-1}$, under a flow of $50 \mathrm{ml} \mathrm{min}^{-1}$ of $\mathrm{N}_{2}$.

Particle size distribution of Verdete was obtained by laser diffraction with a Mastersizer 2000 equipment using isopropyl alcohol as dispersion medium and the Fraunhofer approximation model.

Mass compositions were determined by Wavelength Dispersive X-Ray Fluorescence spectrometry (WDXRF) on a Bruker S8 Tiger equipment, as previously described by Safatle et al. (2020). Prior to characterization, samples were macerated and sieved in a 200-mesh sieve. The passing materials, whose particle diameter is less than $0.075 \mathrm{~mm}$, were used to produce molten glass pellets. In the melting procedure, $1 \mathrm{~g}$ of sample is mixed with $8 \mathrm{~g}$ of a melt material $\left(\mathrm{Li}_{2} \mathrm{~B}_{4} \mathrm{O}_{7}\right)$ in a platinum crucible, which is heated by direct contact with the flame of a Fluxana Vulcan 4MA gasmelting machine. 


\section{Results and Discussion}

\subsection{Characterization of Verdete}

Table 1 (second column) shows the mass fraction of the elements (expressed as equivalent oxides) contained in Verdete (-100 mesh Tyler). Accordingly, the ore is composed mainly of $\mathrm{SiO}_{2}$ (60.29\%), $\mathrm{Al}_{2} \mathrm{O}_{3}(16.04 \%), \mathrm{K}_{2} \mathrm{O}(11.28 \%)$, in addition to other nutrients, such as $\mathrm{Fe}_{2} \mathrm{O}_{3}(7.36 \%)$ and $\mathrm{MgO}(3.1 \%)$. These elements account for $98.07 \%$ of the sample mass. The balance to complete $100 \%$ is probably due to the presence of water and other lighter elements. The distribution of elements in this sample is similar to the distribution of elements in the Verdete sample collected and characterized by Moreira et al. (2016), whose mass fraction of $\mathrm{K}_{2} \mathrm{O}$ varies from 8.5 to $10.6 \%$.

Table 1 - Mass fraction of elements (expressed as equivalent oxides) contained in Verdete and in calcination products VM and VC (-100 mesh Tyler). Results obtained by XRF analysis.

\begin{tabular}{|c|c|c|c|c|}
\hline \multirow{2}{*}{\multicolumn{2}{|c|}{ Oxide }} & \multicolumn{3}{|c|}{ Mass fraction (\%) } \\
\hline & & Verdete & VM & VC \\
\hline \multirow{5}{*}{ 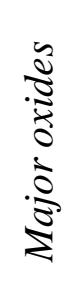 } & $\mathrm{SiO}_{2}$ & 60.29 & 44.77 & 32.02 \\
\hline & $\mathrm{Al}_{2} \mathrm{O}_{3}$ & 16.04 & 11.31 & 7.68 \\
\hline & $\mathrm{K}_{2} \mathrm{O}$ & 11.28 & 8.36 & 7.71 \\
\hline & $\mathrm{Fe}_{2} \mathrm{O}_{3}$ & 7.36 & 5.46 & 6.04 \\
\hline & $\mathrm{MgO}$ & 3.1 & 25.48 & 1.9 \\
\hline \multirow{21}{*}{ 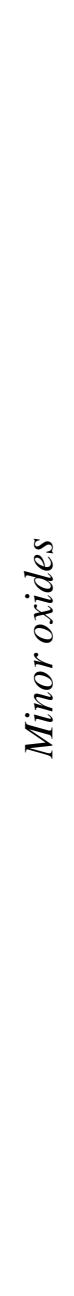 } & $\mathrm{Br}$ & 1.35 & 1.75 & - \\
\hline & $\mathrm{TiO}_{2}$ & 0.93 & 0.67 & 0.64 \\
\hline & $\mathrm{CaO}$ & - & 0.31 & 10.27 \\
\hline & $\mathrm{V}_{2} \mathrm{O}_{5}$ & 0.12 & 0.09 & 0.11 \\
\hline & $\mathrm{P}_{2} \mathrm{O}_{5}$ & 0.09 & 0.09 & 0.11 \\
\hline & $\mathrm{Cl}$ & - & 0.08 & 8.78 \\
\hline & $\mathrm{Rb}_{2} \mathrm{O}$ & 0.06 & - & 0.01 \\
\hline & $\mathrm{MnO}$ & 0.05 & 0.07 & 0.04 \\
\hline & $\mathrm{Pd}$ & - & 0.04 & - \\
\hline & $\mathrm{ZrO}_{2}$ & 0.03 & 0.02 & 0.02 \\
\hline & $\mathrm{ZnO}$ & 0.02 & 0.01 & 0.01 \\
\hline & $\mathrm{Cr}_{2} \mathrm{O}_{3}$ & 0.02 & 0.01 & - \\
\hline & $\mathrm{NiO}$ & 0.01 & 0.01 & $67 \mathrm{ppm}$ \\
\hline & $\mathrm{CuO}$ & - & 0.01 & $64 \mathrm{ppm}$ \\
\hline & $\mathrm{SrO}$ & - & $52 \mathrm{ppm}$ & 0.04 \\
\hline & $\mathrm{CoO}$ & - & 36 ppm & - \\
\hline & $\mathrm{Na}_{2} \mathrm{O}$ & - & - & 0.07 \\
\hline & $\mathrm{BaO}$ & - & - & 0.05 \\
\hline & $\mathrm{Rb}_{2} \mathrm{O}$ & - & - & 0.01 \\
\hline & $\mathrm{Ga}_{2} \mathrm{O}_{3}$ & - & - & $31 \mathrm{ppm}$ \\
\hline & $\mathrm{Nb}_{2} \mathrm{O}_{5}$ & - & - & $21 \mathrm{ppm}$ \\
\hline
\end{tabular}


Figure 1 shows the TG and DTA profiles of Verdete (-100 mesh Tyler). The TG profile shows two distinct regions of mass loss, the first ranging from room temperature to $745 \mathrm{~K}$, and the second to approximately $1140 \mathrm{~K}$. In the first region, mass loss must occur due to expelling of surface and interlayer water molecules. In the second region, mass loss may be due to dehydroxylation of glauconite and muscovite (Rawlley, 1994; Pérez-Maqueda et al., 1994; Tedrow, 1966). The DTA profile shows an endothermic peak with minimum at $965 \mathrm{~K}$ that corresponds to the inflection point of the TG profile situated inside this second region of mass loss. A second endothermic peak, with minimum at $1255 \mathrm{~K}$, also appears in the DTA profile and may corresponds to recrystallization of muscovite or glauconite into other structures. In the case of muscovite, this peak probably indicates its recrystallization into leucite, corundum and mullite (Pérez-Maqueda et al., 1994).

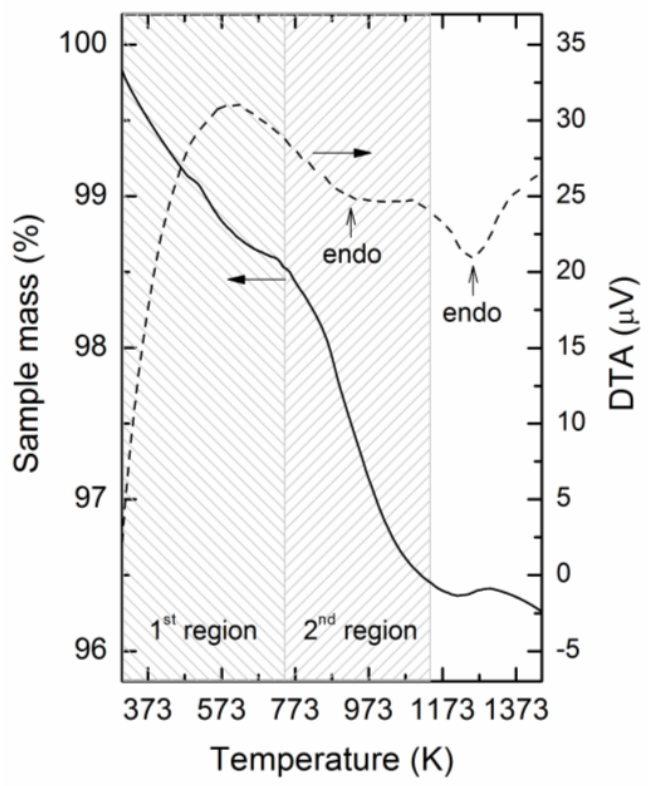

Figure 1 - TG and DTA profiles of Verdete (-100 mesh Tyler).

Figure 2 shows the particle size distribution of Verdete (-100 mesh Tyler). The data was adjusted to the main models available in the literature: GGS (Gates-Gaudim-Shaumann), RRB (Rosin-Rammler-Bennet) and Sigmoid. The GGS model (Equation 2) fitted better to the experimental data, and the parameters obtained after the fitting procedure are shown in the table within Figure 2. The results indicate that $50 \%$ of the particles have a diameter smaller than $36 \mu \mathrm{m}$. In addition, the Sauter mean diameter $\left(d_{32}\right)$ was estimated as $21.925 \mu \mathrm{m}$. In Equation $2, d_{p}$ is the particle size, $X$ is the cumulative fraction, and $k$ and $m$ are estimated parameters.

$X=\left(d_{p} / k\right)^{m}$

\subsection{Calcination of Verdete with $\mathrm{MgCl}_{2}$ and $\mathrm{CaCl}_{2}$}

Calcination of Verdete $(500 \mathrm{~g})$ with $\mathrm{MgCl}_{2} \cdot x \mathrm{H}_{2} \mathrm{O}(175 \mathrm{~g})$ was carried out at $1173 \mathrm{~K}$, with heating rate of $30 \mathrm{~K} \mathrm{~min}^{-1}$ for $1 \mathrm{~h}$. The Verdete ore $(750 \mathrm{~g})$ was also calcined with $\mathrm{CaCl}_{2} \cdot 2 \mathrm{H}_{2} \mathrm{O}(408$ $\mathrm{g}$ ) in the same conditions mentioned previously. The calcination products VM (Verdete + $\mathrm{MgCl}_{2} \cdot x \mathrm{H}_{2} \mathrm{O}$ ) and $\mathrm{VC}\left(\right.$ Verdete $+\mathrm{CaCl}_{2} \cdot 2 \mathrm{H}_{2} \mathrm{O}$ ) were sieved in a 100-mesh sieve and analysed by $\mathrm{XRF}$ and XRD. Table 1 (third and fourth columns) shows the mass fraction of the elements (expressed as equivalent oxides) contained in each calcination product. Figure 3 shows the XRD patterns of Verdete and those of calcination products VM and VC.

After calcination, the mixtures Verdete $/ \mathrm{MgCl}_{2} \cdot x \mathrm{H}_{2} \mathrm{O}$ and Verdete $/ \mathrm{CaCl}_{2} \cdot 2 \mathrm{H}_{2} \mathrm{O}$ lost respectively $5 \%$ and $15 \%$ of their initial mass, probably from loss of surface and interlayer water molecules (from Verdete, $\mathrm{MgCl}_{2} \cdot x \mathrm{H}_{2} \mathrm{O}$ and $\mathrm{CaCl}_{2} \cdot 2 \mathrm{H}_{2} \mathrm{O}$ ) and also due to dehydroxylation of the micas. The mixture Verdete/ $\mathrm{MgCl}_{2} \cdot x \mathrm{H}_{2} \mathrm{O}$ also lost chlorine, probably in the form of $\mathrm{Cl}_{2}$, since the 
XRF analysis (third column of Table 1$)$ detected small amount $(0.08 \%)$ of the element. As expected, the calcination product $\mathrm{VM}$ presents high $\mathrm{MgO}$ content $(25.48 \%)$, while $\mathrm{VC}$ is enriched in $\mathrm{CaO}$ $(10.27 \%)$.

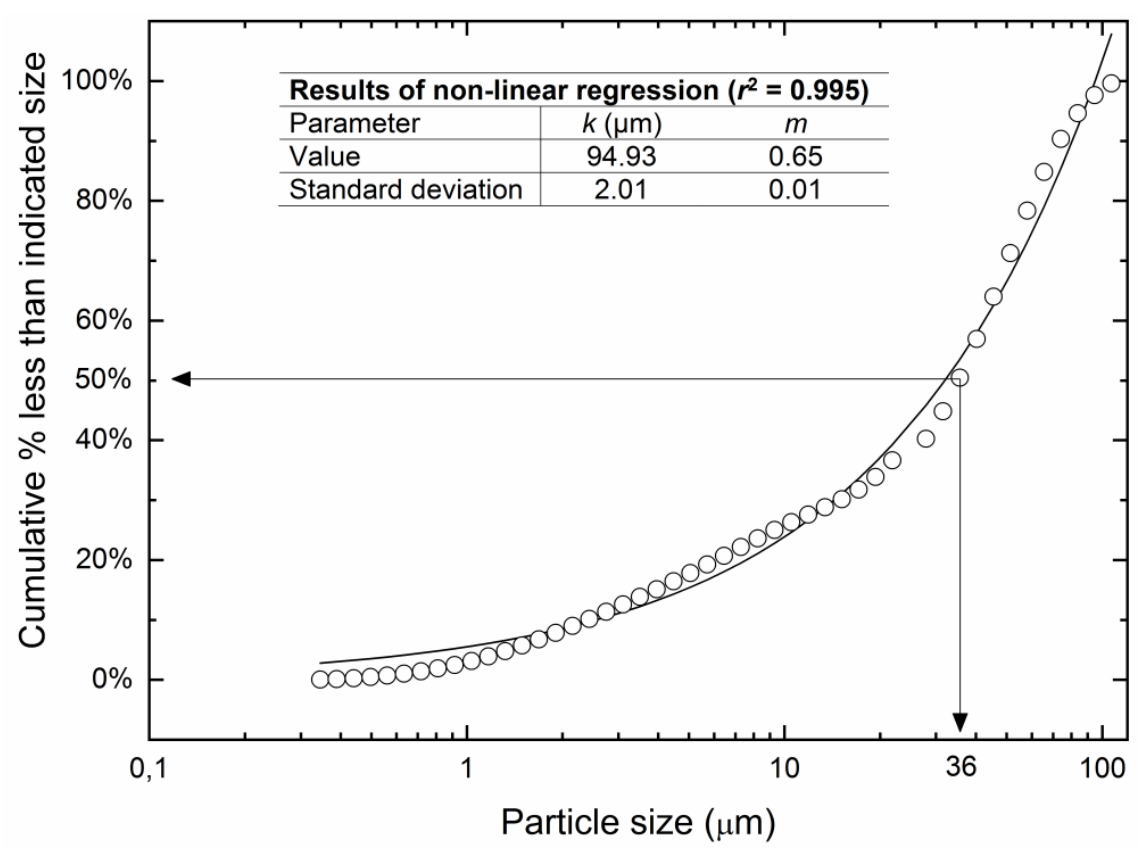

Figure 2 - Particle size distribution of Verdete (-100 mesh Tyler).

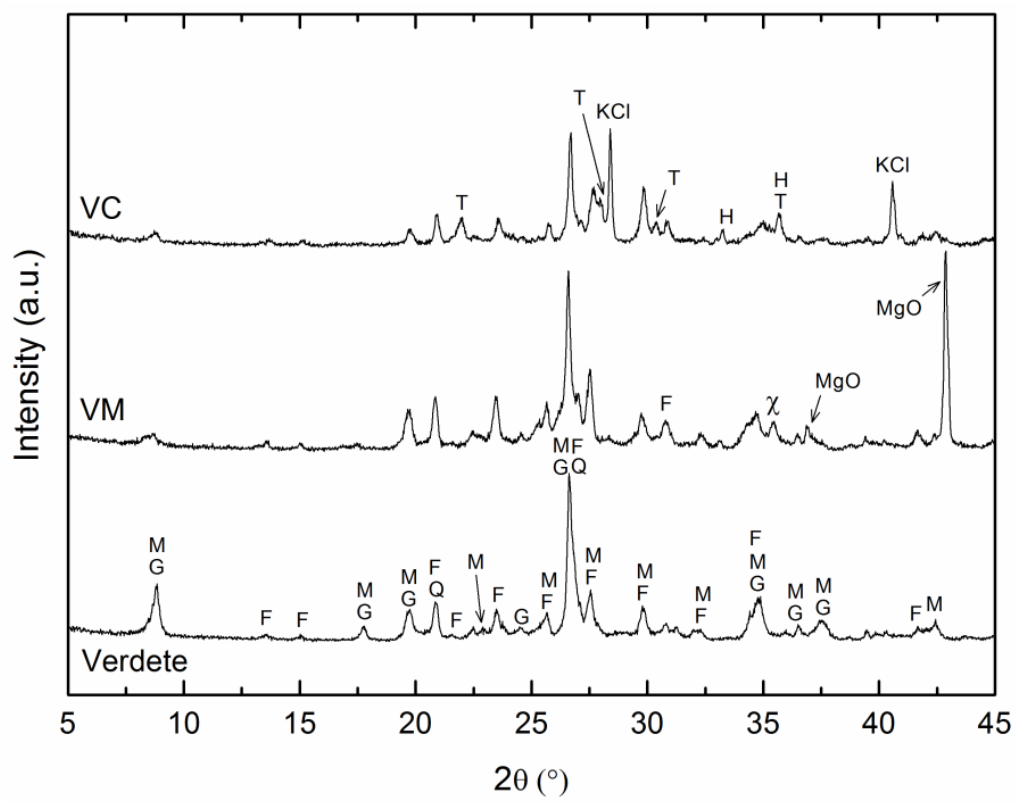

Figure 3 - XRD patterns of (A) Verdete (-100 mesh Tyler) and calcination products thereof with (B) $\mathrm{MgCl}_{2} \cdot x \mathrm{H}_{2} \mathrm{O}$ and (C) $\mathrm{CaCl}_{2} \cdot 2 \mathrm{H}_{2} \mathrm{O}$. Minerals: (F) K-feldspar, (G) glauconite, (H) hematite, $(M)$ muscovite, $(Q)$ quartz and $(T)$ anorthite. $\chi$ may refer to magnetite, magnesioferrite and dehydroxylated muscovite.

According to Figure 3, the Verdete ore consists mostly of quartz, micas (muscovite and glauconite) and K-feldspar, as also reported by Moreira et al. (2016). Diffraction lines at $8.8^{\circ}, 17.7^{\circ}$ and $19.7^{\circ}$, and others with lower intensity are characteristic of muscovite and glauconite. The absence of the diffraction line at approximately $29^{\circ}$, characteristic of diffraction plane $(1 \overline{1} 2)$ of glauconite, indicates that the mineral is probably present in smaller quantities (compared to muscovite), so that the predominant mica must be muscovite. 
After calcination with $\mathrm{MgCl}_{2} \cdot x \mathrm{H}_{2} \mathrm{O}$ (XRD pattern VM in Figure 3) the diffraction lines of micas became less intense and broader, evidencing disorder or even destruction of muscovite and glauconite crystal structures. On the other hand, the diffraction lines of K-feldspar became more intense and narrower, indicating increased crystallinity of its structure. The main product formed after calcination was $\mathrm{MgO}$, whose peaks at $36.9^{\circ}$ and $42.9^{\circ}$ are quite expressive. Formation of $\mathrm{MgO}$ must be due to hydrolysis of $\mathrm{MgCl}_{2} \cdot x \mathrm{H}_{2} \mathrm{O}\left[\mathrm{MgCl}_{2}+x \mathrm{H}_{2} \mathrm{O} \rightarrow \mathrm{MgO}+2 \mathrm{HCl}+(x-1) \mathrm{H}_{2} \mathrm{O}\right]$, which also forms hydrochloric acid as by-product. Therefore, the decrease in diffraction lines characteristic of micas (mentioned previously) may be due to reaction of $\mathrm{HCl}$ with glauconite. It is possible that part of glauconite has transformed into magnetite $\left(\mathrm{Fe}_{3} \mathrm{O}_{4}\right)$ or magnesioferrite $\left(\mathrm{Mg}\left(\mathrm{Fe}^{3+}\right)_{2} \mathrm{O}_{4}\right)$, as evidenced by the appearance of the diffraction line at $35.5^{\circ}$. This diffraction line (at $35.5^{\circ}$ ) may also be associated with the presence of dehydroxylated muscovite, as commented on the TG profile of Verdete (Figure 1) and also discussed by other authors (Rawlley, 1994; Pérez-Maqueda et al., 1994; Tedrow, 1966).

After calcination with $\mathrm{CaCl}_{2} \cdot 2 \mathrm{H}_{2} \mathrm{O}$ (XRD pattern VC in Figure 3 ) the diffraction lines of micas became less intense and broader, similar to what occurred after calcination with $\mathrm{MgCl}_{2} \cdot x \mathrm{H}_{2} \mathrm{O}$. The diffraction lines of feldspar did not appear to have significantly altered, so as the diffraction lines of quartz. Three new structures were formed: anorthite $\left(\mathrm{CaAl}_{2} \mathrm{Si}_{2} \mathrm{O}_{8}\right)$, hematite $\left(\mathrm{Fe}_{2} \mathrm{O}_{3}\right)$ and sylvite $(\mathrm{KCl})$. Diffraction lines of anorthite (at $22^{\circ}, 27.9^{\circ}, 30.4^{\circ}$ ) and sylvite (at $28.4^{\circ}$ and $40.5^{\circ}$ ) were also observed elsewhere (Santos et al., 2017) after calcination of Verdete with $\mathrm{CaCl}_{2} \cdot 2 \mathrm{H}_{2} \mathrm{O}$ at 973 and $1173 \mathrm{~K}$. Jena et al. (2016) also observed the presence of sylvite and anorthite after calcination of feldspar with $\mathrm{CaSO}_{4}$ and $\mathrm{NaCl}$. The salts reacted to form $\mathrm{Na}_{2} \mathrm{SO}_{4}$ and $\mathrm{CaCl}_{2}$, and the latter melted at around $775{ }^{\circ} \mathrm{C}$ and consumed part of the feldspar structure, generating the previously mentioned crystalline phases. The diffraction lines of hematite are less expressive, but indicate that iron $\left(\mathrm{Fe}^{3+}\right)$ was released from the structure of glauconite. Formation of hematite is also confirmed by the colour change of the ore (from dark green to reddish brown) after calcination, as shown in Figure 4.
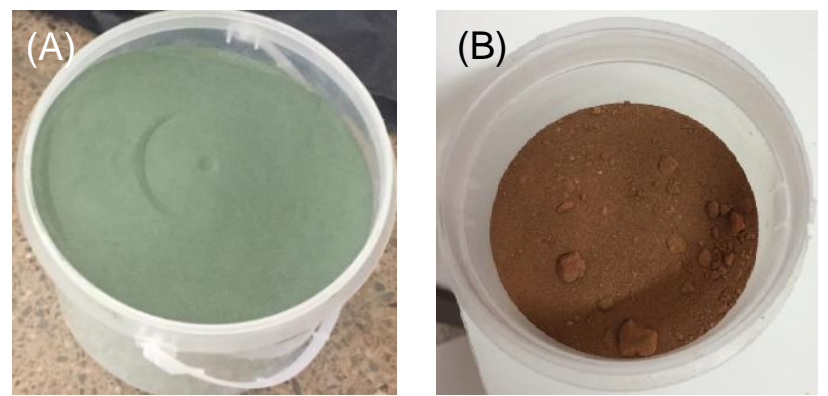

\section{Figure 4 - Colour change of Verdete from (A) dark green to (B) reddish brown after calcination with $\mathrm{CaCl}_{2} \cdot 2 \mathrm{H}_{2} \mathrm{O}$.}

\subsection{Flotation of Verdete}

Table 2 shows the mass recoveries of the seven flotation tests performed with Verdete $(-100$ mesh Tyler). In Test A1, where vegetal oil was used as collector, the sample did not float. In tests conducted with amine as collector and gelatinized cornstarch as depressant (Tests A2-A4) the mass recoveries were relatively low (less than 40\%), but the increase of collector dosage caused an increase in recovery. For instance, lower collector dosage $(100 \mathrm{~g} / \mathrm{t})$ led to lower recovery $(22 \%)$, while higher collector dosage (300 g/t) resulted in higher recovery $(35 \%)$. Since the depressant dosage was fixed at $300 \mathrm{~g} / \mathrm{t}$, the higher recovery at the higher collector dosage level was expected, as a higher collector dosage usually leads to higher recoveries (Santana et al., 2008). Tests A5-A7 were performed with sodium silicate (dosage fixed at $300 \mathrm{~g} / \mathrm{t}$ ) as depressant and amine as collector. Similar to Tests A2-A4, the highest amine dosage led to the largest mass recovery (53\%), which was also the highest recovery observed among all the tests. In Test A7, the floated fraction was composed of $11.8 \% \mathrm{~K}_{2} \mathrm{O}$. 
Table 2 - Mass recoveries of flotation tests performed with Verdete (-100 mesh Tyler).

\begin{tabular}{cccccc}
\hline \multirow{2}{*}{ Test } & \multicolumn{2}{c}{ Collector } & \multicolumn{2}{c}{ Depressant } & Recovery \\
\cline { 2 - 5 } & Type & Dosage $(\mathbf{g} / \mathbf{t})$ & Type & Dosage $(\mathbf{g} / \mathbf{t})$ & $(\boldsymbol{\%})$ \\
\hline A1 & Vegetal oil & 500 & Gelatinized cornstarch & 300 & 0 \\
A2 & Amine & 100 & Gelatinized cornstarch & 300 & 22 \\
A3 & Amine & 200 & Gelatinized cornstarch & 300 & 31 \\
A4 & Amine & 300 & Gelatinized cornstarch & 300 & 35 \\
A5 & Amine & 100 & Sodium silicate & 300 & 24 \\
A6 & Amine & 200 & Sodium silicate & 300 & 30 \\
A7 & Amine & 500 & Sodium silicate & 300 & 53 \\
\hline
\end{tabular}

\subsection{Flotation of Calcination Products}

Table 3 shows the conditions and recoveries of tests performed with calcination product VM. In cases where amine was used as collector (Tests B2 and B3), increasing dosage from 500 to 1000 $\mathrm{g} / \mathrm{L}$ almost doubled mass recovery, from $31 \%$ to $59 \%$. The use of oleic acid as collector (Test B1) decreased mass recovery from $31 \%$ (Test B2) to $14 \%$ (Test B1).

Table 3 - Mass recoveries of flotation tests performed with calcination product VM (-100 mesh Tyler).

\begin{tabular}{cccccc}
\hline \multirow{2}{*}{ Test } & \multicolumn{2}{c}{ Collector } & \multicolumn{2}{c}{ Depressant } & Recovery \\
\cline { 2 - 5 } & Type & Dosage $(\mathbf{g} / \mathbf{t})$ & Type & Dosage $(\mathbf{g} / \mathbf{t})$ & $(\boldsymbol{\%})$ \\
\hline B1 & Oleic acid & 500 & Gelatinized cornstarch & 300 & 14 \\
B2 & Amine & 500 & Gelatinized cornstarch & 300 & 31 \\
B3 & Amine & 1000 & Gelatinized cornstarch & 300 & 59 \\
\hline
\end{tabular}

Table 4 shows the mass fractions of the floated (F) and non-floated (NF) fractions of Tests B1-B3. Figures 5 and 6 show respectively the XRD patterns of the floated and non-floated fractions of these tests.

Table 4 - Mass fractions of flotation tests performed with calcination product VM (-100 mesh Tyler). F and NF account respectively for the floated and non-floated fractions.

\begin{tabular}{l|c|c|c|c|c|c|c}
\hline \multirow{2}{*}{ Oxide } & \multicolumn{9}{|c}{ Mass fraction (\%) } \\
\cline { 2 - 8 } & \multirow{2}{*}{ Cell feed (VM) } & \multicolumn{2}{|c}{ Test B1 } & \multicolumn{2}{c}{ Test B2 } & \multicolumn{2}{c}{ Test B3 } \\
\cline { 2 - 8 } & 44.77 & F & NF & F & NF & F & NF \\
\hline $\mathrm{SiO}_{2}$ & 25.48 & 92.49 & 37.87 & 15.56 & 40.01 & 32.00 & 37.04 \\
$\mathrm{MgO}$ & 11.31 & 1.34 & 11.06 & 7.14 & 11.07 & 9.73 & 10.42 \\
$\mathrm{Al}_{2} \mathrm{O}_{3}$ & 8.36 & 0.81 & 7.72 & 3.56 & 8.36 & 6.25 & 7.77 \\
$\mathrm{~K}_{2} \mathrm{O}$ & 5.46 & 4.13 & 5.47 & 4.94 & 5.46 & 4.64 & 5.74 \\
$\mathrm{Fe}_{2} \mathrm{O}_{3}$ & 3.16 & 0.94 & 1.58 & 1.40 & 1.75 & 1.47 & 1.87 \\
Other oxides & \multicolumn{7}{c}{}
\end{tabular}

According to Table 4, all three tests showed the following trend: concentration of magnesium in the floated fraction and concentration of silicon, aluminium, potassium and iron in the non-floated fraction. Despite the low recovery attained in Test B1 (14\%), the mass fraction of magnesium in the floated fraction (92.49\%) is high. In the XRD patterns of the floated fractions (Figure 5) the diffraction lines at angles smaller than $30^{\circ}$, characteristic of minerals that compose the Verdete ore, such as glauconite, muscovite, K-feldspar and quartz, remain, but with less intensity. Specifically, in the floated fraction of Test B1 (carried out with oleic acid as collector), these diffraction lines are 
the least intense, while the diffraction lines characteristic of $\mathrm{MgO}\left(36.9^{\circ}\right.$ and $\left.42.9^{\circ}\right)$ are the most intense, corroborating with the high mass fraction of $\mathrm{MgO}$ obtained by XRF (Table 4). In Test B1, the diffraction line at $30.25^{\circ}$ is attributed only to magnetite or magnesioferrite, proving the existence of this structure in the calcination product VM. Oleic acid is a long chain fatty acid with 18 carbon atoms in its structure, classified as an anionic collector. Its adsorption on the surface of the minerals is chemical in nature. Thus, the dominant factor for surface hydrophobicity to occur is the existence of elements that form insoluble compounds with the collecting ion. Oleic acid has high affinity for alkaline earth metals $\left(\mathrm{Ca}^{2+}, \mathrm{Mg}^{2+}, \mathrm{Ba}^{2+}\right.$ and $\left.\mathrm{Sr}^{2+}\right)$, with which it forms poorly soluble salts (Monte and Peres, 2010). The mass fractions of $\mathrm{MgO}$ in the floated fractions of Tests $\mathrm{B} 2(58.43 \%)$ and $\mathrm{B} 3$ $(44.17 \%)$ are much smaller than that obtained in the floated fraction of Test B1 (92.49\%). However, in spite of the lower efficiency of amine (Tests B2-B3) in relation to oleic acid (Test B1), there was still a concentration of magnesium in the floated fractions of these tests when compared to the feed (25.48\%). Amines ionize by protonation when in contact with water $\left(\mathrm{RNH}_{2(\mathrm{aq})}+\mathrm{H}_{2} \mathrm{O}_{(\mathrm{l})} \rightarrow \mathrm{RNH}_{3}{ }^{+}\right.$(aq) $+\mathrm{OH}_{(}^{-}$aq) $)$. In acidic or low alkaline $\mathrm{pH}$, the ionic species $\left(\mathrm{RNH}_{3}{ }^{+}\right)$predominates, while in more alkaline $\mathrm{pH}$ the molecular species $\left(\mathrm{RNH}_{2}\right)$ becomes predominant. At $\mathrm{pH}$ values between 9 and 11 (which is the case of this work, i.e., $\mathrm{pH}=10$ ), the two species coexist, acting as collector $\left(\mathrm{RNH}_{3}{ }^{+}\right)$ and frother $\left(\mathrm{RNH}_{2}\right)$, respectively (Rodrigues et al., 2010). Therefore, when immersed in alkaline medium, the surface of $\mathrm{MgO}$ particles is coated by negative charges, increasing their adsorption capacity in the ionized amine (Monte and Peres, 2010).

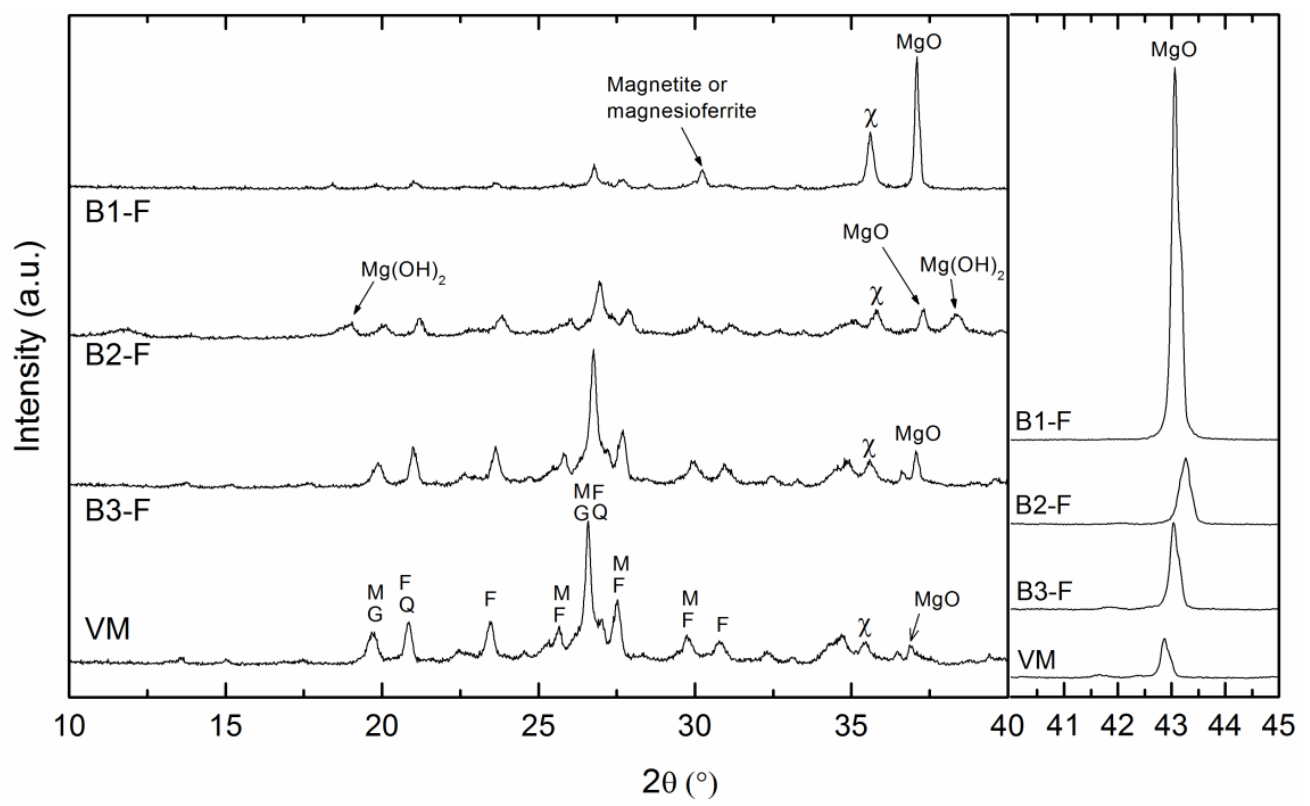

Figure 5 - XRD patterns of floated fractions of flotation tests performed with the calcination product VM. Minerals: (F) K-feldspar, (G) glauconite, (M) muscovite and (Q) quartz. $\chi$ may refer to magnetite, magnesioferrite and dehydroxylated muscovite.

Four flotation tests $(\mathrm{C} 1-\mathrm{C} 4)$ were performed with calcination product $\mathrm{VC}$, using amine Flotigam EDA and oleic acid as collectors, and gelatinized cornstarch as depressant. Mass recoveries of these tests are shown in Table 5. Faced with such low recovery values (below 4\%), it can be assumed that flotation did not occurs in Tests C1, C3 and C4. In Test C2 the mass recovery attained a value of $13 \%$, which is still not expressive. 


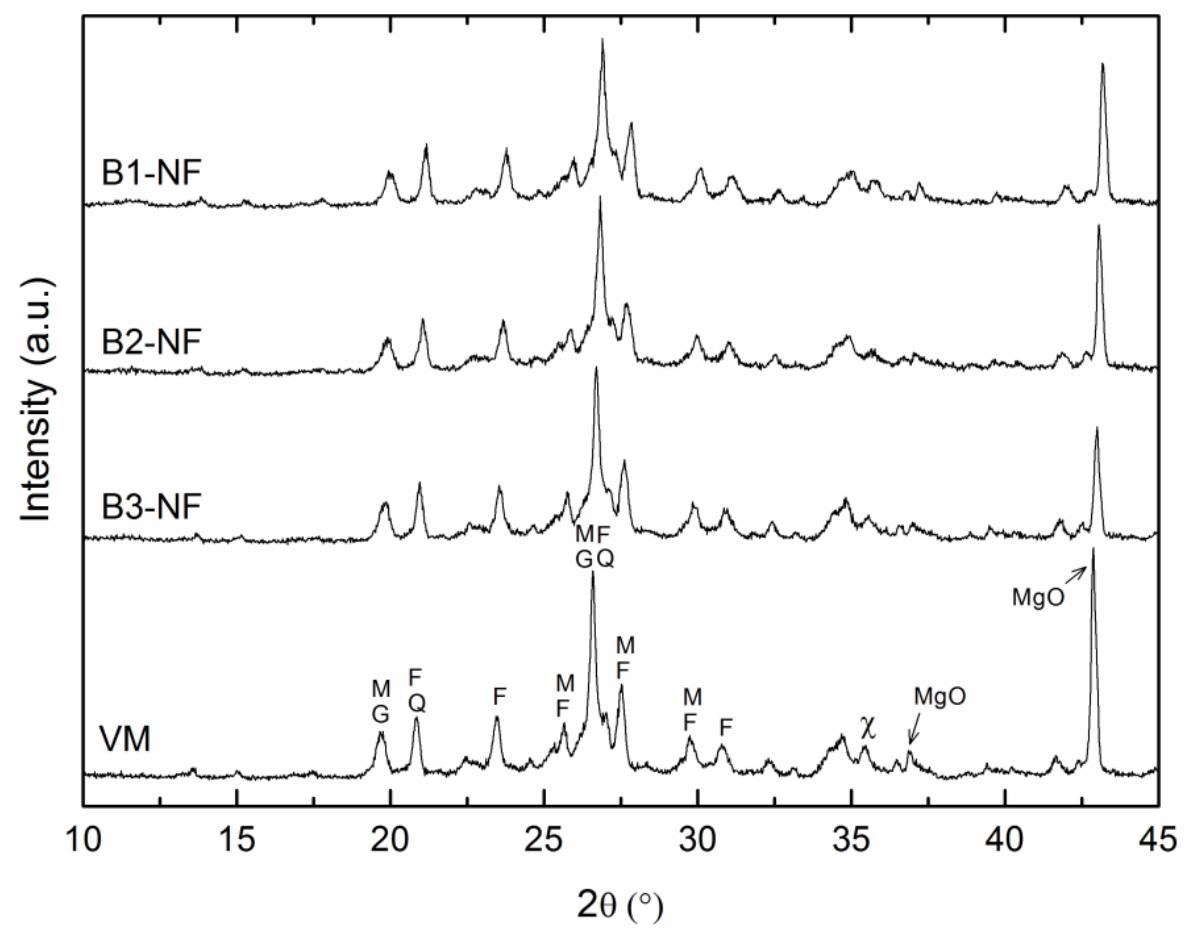

Figure 6 - XRD patterns of non-floated fractions of flotation tests performed with the calcination product VM. Minerals: (F) K-feldspar, (G) glauconite, (M) muscovite and (Q) quartz. $\chi$ may refer to magnetite, magnesioferrite and dehydroxylated muscovite.

Table 5 - Mass recoveries of flotation tests performed with calcination product VC (-100 mesh Tyler).

\begin{tabular}{cccccc}
\hline \multirow{2}{*}{ Test } & \multicolumn{2}{c}{ Collector } & \multicolumn{2}{c}{ Depressant } & Recovery \\
\cline { 2 - 5 } & Type & Dosage (g/t) & Type & Dosage (g/t) & $(\%)$ \\
\hline C1 & Amine & 500 & Gelatinized cornstarch & 300 & 2 \\
C2 & Amine & 1000 & Gelatinized cornstarch & 300 & 13 \\
C3 & Oleic acid & 500 & Gelatinized cornstarch & 300 & 1 \\
C4 & Oleic acid & 1000 & Gelatinized cornstarch & 300 & 4 \\
\hline
\end{tabular}

\section{Conclusion}

Verdete ore was calcined with $\mathrm{MgCl}_{2} \cdot x \mathrm{H}_{2} \mathrm{O}$ and $\mathrm{CaCl}_{2} \cdot 2 \mathrm{H}_{2} \mathrm{O}$, and the calcination products, as well as Verdete itself, were subjected to cell flotation. Three types of collectors were used to evaluate the recovery efficiency: oleic acid, vegetal oil and amine (Flotigam EDA). Mass recoveries of flotation tests carried out with Verdete reached a maximum value of $53 \%$ in the case where amine was used as collector $(500 \mathrm{~g} / \mathrm{t})$ and sodium silicate as depressant $(300 \mathrm{~g} / \mathrm{t})$. After calcination of Verdete with $\mathrm{MgCl}_{2} \cdot x \mathrm{H}_{2} \mathrm{O}$, partial consumption of the micas and formation of $\mathrm{MgO}$ occurred. This calcination product was floated using amine or oleic acid as collectors and gelatinized cornstarch as depressant. Amine $(1,000 \mathrm{~g} / \mathrm{L})$ was the collector that showed the highest recovery efficiency $(59 \%)$. A significantly lower mass recovery $(13 \%)$ was obtained when using the same type and collector dosage, however for the calcination product of Verdete with $\mathrm{CaCl}_{2} \cdot 2 \mathrm{H}_{2} \mathrm{O}$. Two types of depressants were also evaluated: gelatinized cornstarch and sodium silicate, which showed good recovery performances for Verdete (53\%, sodium silicate) and for the calcination product with $\mathrm{MgCl}_{2} \cdot x \mathrm{H}_{2} \mathrm{O}$ (59\%, gelatinized cornstarch). The results suggest that mineral recovery does not depend on the type of depressant, but is directly proportional to the dosage and type of collector. 


\section{Acknowledgements}

The authors would like to thank FAPEMIG (Minas Gerais Research Foundation) and ProPP/UFU (Pro-Rectory of Research and Postgraduate Studies of the Federal University of Uberlândia) for financial support. Prof. Carlos Henrique Ataíde (FEQUI/UFU), Roni Marcos dos Santos (IQ/UFU) and the Multi-User Laboratory of UFU are also acknowledged.

\section{References}

Larsen, E., Kleiv, R. A. (2016). Flotation of quartz from quartz-feldspar mixtures by the HF method. Minerals Engineering, 98, 49-51. doi: https://doi.org/10.1016/j.mineng.2016.07.021

El-Salmawy, M. S., Nakahiro, Y., Wakamatsu, T. (1993). The role of alkaline earth cations in flotation separation of quartz from feldspar. Minerals Engineering, 6(12), 1231-1243. doi: https://doi.org/10.1016/0892-6875(93)90101-R

Huang, Z., Cheng, C., Zhong, H., Li, L., Guo, Z., Yu, X., He, G., Han, H., Deng, L., Fu, W. (2019) Flotation of sylvite from potash ore by using the Gemini surfactant as a novel flotation $\begin{array}{lllll}\text { collector. } & \text { Minerals } & \text { Engineering, 22-26. }\end{array}$ https://doi.org/10.1016/j.mineng.2018.11.055

Jena, S. K., Misra, P. K., Das, B. (2016). Studies on extraction of potassium from feldspar by roastleach method using phosphogypsum and sodium chloride. Mineral Processing and Extractive Metallurgy Review, 37(5), 323-332. doi: https://doi.org/10.1080/08827508.2016.1218869

Moreira, D. S., Uhlein, A., Fernandes, M. L. S., Mizusaki, A. N., Galéry, R., Delbem, I. D. (2016). Estratigrafia, petrografia e mineralização de potássio em siltitos verdes do grupo Bambuí na região de São Gotardo, Minas Gerais. Geociências, 35(2), 157-171.

Rawlley, R. K. (1994). Mineralogical investigations on an Indian glauconitic sandstone of Madhya Pradesh state. Applied Clay Science, 8(6), 449-465. doi: https://doi.org/10.1016/0169$\underline{1317(94) 90039-6}$

Pérez-Maqueda, L. A., Blanes, J. N., Pascual, J., Pérez-Rodríguez, J. L. (2004). The influence of sonication on the thermal behavior of muscovite and biotite. Journal of the European Ceramic Society, 24(9), 2793-2801. doi: https://doi.org/10.1016/j.jeurceramsoc.2003.10.002

Tedrow, J. C. F. (1966). Properties of sand and silt fractions in New Jersey soils. Soil Science, 101(1), 24-30.

Safatle, F. A., Oliveira, K. D., Ávila-Neto, C. N. (2020). Potassium recovery from Brazilian glauconitic siltstone by hydrothermal treatments. REM - International Engineering Journal, 73, 213-224. doi: http://dx.doi.org/10.1590/0370-44672019730047

Santos, W. O., Mattiello, E. M., Costa, L. M., Abrahão, W. A. P., Novais, R. F., Cantarutti, R. B. (2015). Thermal and chemical solubilization of verdete for use as potassium fertilizer. International Journal of Mineral Processing, 140, 72-78. doi: https://doi.org/10.1016/j.minpro.2015.05.003

Santos, W. O., Mattiello, E. M., Pacheco, A. A., Vergutz, L., Souza-Filho, L. F. S., Abdala, D. B. (2017). Thermal treatment of a potassium-rich metamorphic rock in formation of soluble K forms. International Journal of Mineral Processing, 159, 16-21. doi: https://doi.org/10.1016/j.minpro.2016.12.004

Santana R. C., Farnese, A. C. C., Fortes, M. C. B., Ataíde, C. H., Barrozo, M. A. S. (2008). Influence of particle size and reagent dosage on the performance of apatite flotation. Separation and Purification Technology, 64(1), 8-15. doi: https://doi.org/10.1016/j.seppur.2008.09.004

Monte, M. B. M., Oliveira, J. F. (2004) Flotation of sylvite with dodecylamine and the effect of added long chain alcohols. Minerals Engineering, 17(3), 425-430, doi: https://doi.org/10.1016/j.mineng.2003.11.005

Monte, M. B. M., Peres, A. E. C. (2010). Capítulo 10 - Química de superfície na flotação. In: Luz, A. B., Sampaio, J. A., França, S. C. A. Tratamento de Minérios. CETEM/MCT.

Rodrigues, O. M. S, Araujo, A.C., Peres, A. E. C. (2010). Microflotação de caulinita utilizando aminas. Rem: Revista Escola de Minas, 63, 661-666. doi: http://dx.doi.org/10.1590/S037044672010000400010 
Schimicoscki, R. S., Oliveira, K. D., Ávila-Neto, C. N. (2020). Potassium recovery from a Brazilian glauconitic siltstone via reaction with sulfuric acid in hydrothermal conditions. Hydrometallurgy, 191, 105251. doi: https://doi.org/10.1016/j.hydromet.2020.105251

Sulaymonova, V. A., Fuchs, M. C., Gloaguen, R., Möckel, R., Merchel, S., Rudolph, M., Krbetschek, M. R. (2018). Feldspar flotation as a quartz-purification method in cosmogenic nuclide dating: A case study of fluvial sediments from the Pamir. MethodsX, 5, 717-726. doi: https://doi.org/10.1016/j.mex.2018.06.014

Tomaz, M. R. C., Ávila-Neto, C. N. (2021). Kinetic model based on initial rates of alkali hydrothermal dissolution of Verdete rock. Hydrometallurgy, 202, 105620. doi: https://doi.org/10.1016/j.hydromet.2021.105620

Yuan, B., Li, C., Liang, B., Lü, L., Yue, H., Sheng, H., Ye, L., Xie, H. (2015). Extraction of potassium from K-feldspar via the $\mathrm{CaCl}_{2}$ calcination route. Chinese Journal of Chemical Engineering, 23(9), 1557-1564. doi: https://doi.org/10.1016/j.cjche.2015.06.012 